\title{
Preparation of $\boldsymbol{\beta}$-Carotene Enriched Pearl Millet Based Cookies
}

\author{
A.A. Kulthe", S.S. Thorat and S.B. Lande \\ Department of Food Science and Technology, MPKV, Rahuri - 413 722, (M.S.) India \\ *Corresponding author
}

\begin{tabular}{|c|c|}
\hline & A B S T R A C T \\
\hline $\begin{array}{l}\text { Cookies, Pearl } \\
\text { millet flour, } \\
\text { Microencapsulated } \\
\beta \text {-carotene, Physical } \\
\text { characteristics, } \\
\text { Sensory quality, } \\
\text { Textural properties }\end{array}$ & \multirow{3}{*}{$\begin{array}{l}\text { Cookies were prepared by substituting maida with pearl millet flour (PMF) } \\
\text { (60:40) and enriched with microencapsulated } \beta \text {-carotene (MBC) powder at } 2,4 \\
\text { and } 6 \% \text { levels. Cookies were evaluated for physico-chemical, sensory and } \\
\text { textural quality parameters. Incorporation of MBC in pearl millet based } \\
\text { cookies resulted in considerable improvement in } \beta \text {-carotene and total } \\
\text { antioxidant activity of cookies when compared to maida with PMF, whereas } \\
\text { calorific value was found to be slightly decreased. The spread ratio and spread } \\
\text { factor were more or less same as compared to control sample. The colour } \\
\text { values } L^{*} \text { and } a^{*} \text { decreased while } b^{*} \text { increased with the addition of MBC to } \\
\text { the cookies. The hardness, breaking strength and cutting strength of cookies } \\
\text { were decreased with the incorporation of MBC in pearl millet based cookies. } \\
\text { The supplementation of } 4 \% \text { MBC was found to be excellent for preparation of } \\
\beta \text {-carotene enriched pearl millet based cookies without affecting the overall } \\
\text { quality. }\end{array}$} \\
\hline Article Info & \\
\hline & \\
\hline
\end{tabular}

\section{Introduction}

Today, in the $21^{\text {st }}$ century, the existence of vitamin A deficiency or VAD, is a major blow to most of us. Its mere existence in both controlled and uncontrolled form is a sorrow in itself. Vitamin A which is an important nutrient for the proper functioning of the eyes, heart, lungs, kidneys, the immune system, and the reproductive system, is also very vital for pregnant women. It is mostly found in fish, meat, poultry, eggs, fruits and vegetables (the most common dietary supplements being $\beta$ carotene in fruits and vegetables) is in controlled form in almost all the North American countries, most of the European nations. On the other hand, many Asian countries apart from Japan and Russia (the part falling in Asia), seriously suffer from VAD. In a shockingly sad manner, India has been categorized as "clinical" by WHO, when it comes to VAD. In simpler words, India has serious vitamin A deficiency (Singh, 2014). Therefore, one of the great challenges today is to develop inexpensive foods that are nutritionally superior and at the same time highly acceptable to intended consumer.

In recent years, there is a trend towards a healthier way of living, which includes a growing awareness by consumers of what they eat and what benefits certain ingredients 
have in maintaining good health. Preventing illness by diet is a unique opportunity for innovative so-called functional foods (Sheehy and Morrissey, 1998). $\beta$-carotene which is a coloured substance having potential for use in food and nutraceutical preparations. However, creating water dispersible form of carotenoids is difficult because of limited solubility of pure carotene crystals. Encapsulation is a potential approach to transform liquids into stable and free flowing powders which are easy to handle and incorporate into dry food systems.

With the increasing knowledge of the positive functions of $\beta$-carotene, more and more people take interest in some foods or pharmaceuticals containing $\beta$-carotene ingredients, such as beverages, baked goods, oils, capsules and tablets. Lipid-soluble vitamins such as vitamin $\mathrm{A}, \beta$-carotene and vitamins $\mathrm{D}, \mathrm{E}$ or $\mathrm{K}$ are much easier to encapsulate than water-soluble ingredients (Kowalski et al., 2000).

Hence, seeing the severity of nutritional deficiency diseases particularly vitamin A, the present study was undertaken to evaluate enrichment of pearl millet based cookies with microencapsulated $\beta$-carotene powder and study its effect on the physico-chemical, sensory and textural characteristics of cookies.

\section{Materials and Methods}

Materials: The raw materials such as maida, pearl millet flour, sugar, vanaspati, sodium bicarbonate, ammonium bicarbonate, etc. were purchased from local market of Rahuri. Microencapsulated $\beta$-carotene powder was prepared in the laboratory by spray drying.

Preparation of cookies: Cookies were prepared using the traditional creamery method. The ingredients included (g) wheat maida 60, pearl millet flour 40, sugar 50, vanaspati 50, ammonium bicarbonate 0.5 , sodium bicarbonate 0.5 , and required amount of water. Cookies were enriched with microencapsulated $\beta$-carotene (MBC) powder at 2, 4 and $6 \%$. The cookies were evaluated for physico-chemical, sensory and textural quality.

Sensory evaluation: The cookies were evaluated for sensory attributes by a panel of 14 semi-trained judges, using a 9 point Hedonic scale system for different parameters like colour and appearance, texture and grain, flavour, crispiness, taste and overall acceptability. The mean values of 6 semitrained judges were considered for evaluating the quality.

Chemical parameters: The $\beta$-carotene content of cookies was determined by spectrophotometric method as suggested by Srivastava and Kumar (2009). The total antioxidant activity of cookies was determined FRAP assay.

Physical parameters: Weight, diameter, thickness, spread ratio and \% spread factor of cookies were estimated as per AACC (1976) methods.

Colour values: The colour scanning machine (Model: Colour Flex EZ) was used for the measurement of colour of cookies. The colour was measured by using CIELAB scale at $10^{\circ}$ observer at D65 illuminant. The cookies sample was placed in the sample cup and the reading in terms of $L^{*}, a^{*}$ and $b^{*}$ were measured. The deviation of the colour of the sample to standard was observed and recorded in the computer interface.

Textural characteristics of cookies: Textural characteristics of cookies such as hardness, breaking strength and cutting strength of cookies were measured using 
Instron Universal Texturometer (Shimadzu AG-Xplus). Each cookie was placed on the loading cell and compressed as per the standard procedures given by Singh et al., (1993).

Statistical analysis: The data obtained was analyzed statistically to determine statistical significance of treatments. Completely Randomized Design (CRD) was used to test the significance of results (Panse and Sukhatme, 1967).The analysis of variance revealed at significance of $\mathrm{p}<0.05$ level, S.E. and C.D. at $5 \%$ level was mentioned wherever required.

\section{Results and Discussion}

\section{$\beta$-carotene content and total antioxidant} activity of cookies:

The data about $\beta$-carotene content and total antioxidant activity of cookies incorporated with $40 \%$ PMF (var. Dhanshakti) and varying levels of MBC powder is presented in table 1. Incorporation of $\mathrm{MBC}$ resulted in considerable improvement in $\beta$-carotene content of cookies. The statistical analysis of $\beta$-carotene content revealed that there was significant increase in the $\beta$-carotene content $(p>0.05)$ of cookies from 0.49 to 3.92 $\mathrm{mg} / 100 \mathrm{~g}$ after addition of $6 \% \mathrm{MBC}$. It is clear that sample $\mathrm{C}_{3}$ contains the highest amount of $\beta$-carotene as compared to the other samples. $\beta$-carotene content of sample $\mathrm{C}_{0}, \mathrm{C}_{1}, \mathrm{C}_{2}$ and $\mathrm{C}_{3}$ was $0.49,1.18,2.56$ and $3.53 \mathrm{mg} / 100 \mathrm{~g}$, respectively which was found in consistent with the added amount of MBC. The freshly baked MBC incorporated cookies retained about $79 \%$ of $\beta$-carotene. This showed that processing of cookies did not much affect the final $\beta$-carotene of cookies prepared with addition of microencapsulated powder.

Bauernfeind et al., (1958) and Bunnel et al., (1958) reported $74-95 \%$ retention of total $\beta$ - carotene in cookies, pie crust and yellow cakes. Rogers et al., (1993) reported 30\% $\beta$ carotene losses during baking of cookies. They also observed that prebaking processing steps had little or no adverse effect on the stability or isomeric distribution on added $\beta$ carotene to baked products (yellow layer cake, sugar cookies and bagels) rather loss was during baking. Park et al., (1997) observed similar results for $\beta$-carotene retention in white bread fortified with cold water-dispersible $\beta$-carotene. Gayas et al., (2012) reported linear increase in $\beta$-carotene content from 0.10 to $2.49 \mathrm{mg} / 100 \mathrm{~g}$ due to increase in the level of carrot pomace powder up to $10 \%$ in defatted soy flour fortified biscuits.

It was clear that sample $\mathrm{C}_{3}$ has the highest level of total antioxidant activity. It was found that control sample had the lowest total antioxidant activity $(11.76 \mathrm{mMol} / \mathrm{kg})$. Total antioxidant activity of sample $\mathrm{C}_{1}, \mathrm{C}_{2}$ and $\mathrm{C}_{3}$ was $14.84,16.18$ and $19.43 \mathrm{mmol} / \mathrm{kg}$, respectively. Thus the addition of MBC resulted in increased total antioxidant activity of cookies from 11.76 to $19.43 \mathrm{mmol} / \mathrm{kg}$, which provided the prominent health benefits. Total antioxidant activity was expressed in TEAC i.e. Trolox Equivalent Antioxidant Activity. Thus total antioxidant activity of sample $\mathrm{C}_{0}, \mathrm{C}_{1}, \mathrm{C}_{2}$ and $\mathrm{C}_{3}$ was equivalent to that of a solution 11.76, 14.84, 16.18 and $19.43 \mathrm{mmol}$ of Trolox calculated experimentally by the FRAP method.

The antioxidant activity of control sample was attributed to the phenolic compounds present in PMF. The addition of MBC contributed to high content of $\beta$-carotene, thus resulting in high total antioxidant activity in cookies. The incorporation of PMF and MBC into cookies increased health benefits by increasing antioxidant properties and dietary fiber content. The results obtained are in good agreement with the results reported by the 
Volker et al., (2002). Ajila et al., (2008) reported increase in total antioxidant activity of biscuits incorporated with mango peel powder. Moore et al., (2009) reported that baking improved the antioxidant availability in whole-wheat pizza crust.

\section{Sensory evaluation of cookies}

The data (Table 2) clearly indicates that the average score for colour and appearance of $\beta$ carotene enriched pearl millet based cookies ranged from 7.00 to 7.75 whereas the minimum score 7.00 was observed in control sample $\left(\mathrm{C}_{0}\right)$. However maximum score 7.75 observed in samples $\mathrm{C}_{3}$. This may be due to effect of addition of highest level of MBC powder containing maltodextrin. The treatment $\mathrm{C}_{2}$ obtained higher scores of texture and grain (7.7), taste (8.00) and overall acceptability (7.64) as compared to control and other samples. It was observed that, the scores for colour and appearance, flavor and crispiness was higher i.e. 7.67, 7.50 and 7.71, respectively in $\mathrm{C}_{3}$ sample. The treatment $\mathrm{C}_{2}$ was found to be better and was mostly acceptable. Thus on overall acceptability score, $\mathrm{C}_{2}$ was considered as standardized and used for further storage studies.

Sudha et al., (2007) reported improvement in sensory qualities of biscuits containing maltodextrin and polydextrose. Gayas et al., (2012) reported improvement in colour and other sensory characteristics of carrot pomace powder incorporated with defatted soy flour fortified biscuits.

\section{Physical characteristics of cookies}

It was observed that addition of MBC had very less effect on the physical parameters of cookies (Table 3). There was slight decrease in the diameter of cookies from 46.37 to $46.21 \mathrm{~mm}$ with increasing proportion of MBC. There was also increase in thickness from 11.37 to $11.42 \mathrm{~mm}$. No trend was observed for weight of cookies because baking was not performed under strict conditions of temperature and humidity.

The spread ratio of cookies decreased significantly from 4.08 to 4.05 with increasing level of MBC. The spread factor of cookies decreased from 100 to $99.27 \%$ with increased addition of MBC. The decreased spread ratio and spread factor may be due to dilution of gluten in cookies with maltodextrin. Also gluten influenced the diameter and spread onset time which is again dependent on the amount free water available to the non-gluten constituents (Bram et al., 2008).

Sudha et al., (2007) reported similar results for physical qualities of biscuits containing maltodextrin and polydextrose. They reported little effect of maltodextrin and polydextrose on thickness and spread of biscuits.

\section{Colour evaluation of cookies}

Addition of MBC showed improvement in the colour values of cookies (Table 4). The $L^{*}$ value increased with the increase in the levels of MBC. Control cookies had the lowest brightness compared to the MBC enriched cookies. No specific trend is seen in the change in $a^{*}$ value upon addition of MBC. The change in $b^{*}$ value, which indicates the yellowness, gradually increased with increase in MBC level.

The colour of cookies was more attributed to the PMF rather MBC as the content of PMF was greater in comparison to MBC. Addition of MBC caused slight bleaching effect on the colour of the cookies. Slightly lower redness and higher brightness in cookies incorporated with MBC might be due to interaction of yellowness of MBC with other ingredients of cookie dough. Similar results were reported by Mridula (2011) for $\beta$-carotene biscuits fortified with defatted soy flour. 
Table. $1 \beta$-Carotene content and total antioxidant activity of cookies*

\begin{tabular}{|c|c|c|}
\hline Treatments & $\begin{array}{c}\boldsymbol{\beta} \text {-carotene content } \\
(\mathbf{m g} / \mathbf{1 0 0 g})\end{array}$ & $\begin{array}{c}\text { Total antioxidant } \\
\text { activity }(\mathbf{m m o l} / \mathbf{k g})\end{array}$ \\
\hline Control & 0.49 & 11.76 \\
\hline $\mathrm{C}_{1}$ & 1.18 & 14.84 \\
\hline $\mathrm{C}_{2}$ & 2.56 & 16.18 \\
\hline $\mathrm{C}_{3}$ & 3.53 & 19.43 \\
\hline SE \pm & 0.387 & 0.261 \\
\hline CD at 5\% & 1.167 & 0.789 \\
\hline
\end{tabular}

Each value is the average of three observations

*Cookies (40\% PMF) from Dhanshakti variety

$\mathrm{C}_{0}=$ Cookies without (MBC), $\mathrm{C}_{1}=2 \% \mathrm{MBC}, \mathrm{C}_{2}=4 \% \mathrm{MBC}, \mathrm{C}_{3}=6 \% \mathrm{MBC}$

Table.2 Sensory evaluation of cookies*

\begin{tabular}{|l|c|c|c|c|c|c|}
\hline $\begin{array}{l}\text { Treat- } \\
\text { ments }\end{array}$ & $\begin{array}{c}\text { Colour and } \\
\text { appearance }\end{array}$ & $\begin{array}{c}\text { Texture } \\
\text { and } \\
\text { grain }\end{array}$ & Flavour & Crispiness & Taste & $\begin{array}{c}\text { Overall } \\
\text { acceptability }\end{array}$ \\
\hline $\mathrm{C}_{0}$ & 7.00 & 7.50 & 7.00 & 7.29 & 7.36 & 7.23 \\
\hline $\mathrm{C}_{1}$ & 7.17 & 7.67 & 7.17 & 7.33 & 7.50 & 7.37 \\
\hline $\mathrm{C}_{2}$ & 7.67 & 7.71 & 7.33 & 7.50 & 8.00 & 7.64 \\
\hline $\mathrm{C}_{3}$ & 7.75 & 7.50 & 7.50 & 7.71 & 7.83 & 7.57 \\
\hline SE \pm & 0.387 & 0.261 & 0.397 & 0.265 & 0.219 & 0.229 \\
\hline CD at 5\% & 1.167 & 0.789 & 1.196 & 0.799 & 0.661 & 0.691 \\
\hline
\end{tabular}

Each value is the average of three observations

*Cookies (40 \% PMF) from Dhanshakti variety

$\mathrm{C}_{0}=$ Cookies without (MBC), $\mathrm{C}_{1}=2 \% \mathrm{MBC}, \mathrm{C}_{2}=4 \% \mathrm{MBC}, \mathrm{C}_{3}=6 \% \mathrm{MBC}$

Table.3 Physical parameters of cookies*

\begin{tabular}{|c|c|c|c|c|c|}
\hline $\begin{array}{c}\text { Treat- } \\
\text { ments }\end{array}$ & $\begin{array}{c}\text { Weight } \\
(\mathbf{g})\end{array}$ & $\begin{array}{c}\text { Diameter } \\
(\mathbf{m m})\end{array}$ & $\begin{array}{c}\text { Thickness } \\
(\mathbf{m m})\end{array}$ & Spread ratio & $\begin{array}{c}\text { Spread } \\
\text { factor }(\boldsymbol{\%})\end{array}$ \\
\hline $\mathrm{C}_{0}$ & 9.71 & 46.37 & 11.37 & 4.08 & 100 \\
\hline $\mathrm{C}_{1}$ & 9.72 & 46.33 & 11.38 & 4.07 & 99.76 \\
\hline $\mathrm{C}_{2}$ & 9.72 & 46.28 & 11.39 & 4.06 & 99.51 \\
\hline $\mathrm{C}_{3}$ & 9.71 & 46.21 & 11.42 & 4.05 & 99.27 \\
\hline SE \pm & 0.004 & 0.002 & 0.003 & -- & -- \\
\hline CD at 5\% & 0.011 & 0.007 & 0.010 & -- & -- \\
\hline
\end{tabular}

Each value is the average of three observations

*Cookies (40\% PMF) from Dhanshakti variety

$\mathrm{C}_{0}=$ Cookies without (MBC), $\mathrm{C}_{1}=2 \% \mathrm{MBC}, \mathrm{C}_{2}=4 \% \mathrm{MBC}, \mathrm{C}_{3}=6 \% \mathrm{MBC}$ 
Table.4 Colour values of cookies*

\begin{tabular}{|c|c|c|c|c|c|}
\hline \multirow{2}{*}{ Treatments } & \multicolumn{5}{|c|}{ Colour values } \\
\cline { 2 - 6 } & $\boldsymbol{L}^{*}$ & $\boldsymbol{a}^{*}$ & $\boldsymbol{b}^{*}$ & $\boldsymbol{C}^{*}$ & $\boldsymbol{H}^{*}$ \\
\hline $\mathrm{C}_{0}$ & 58.710 & 3.393 & 17.708 & 18.030 & 79.121 \\
\hline $\mathrm{C}_{1}$ & 58.575 & 3.310 & 17.973 & 18.275 & 79.565 \\
\hline $\mathrm{C}_{2}$ & 57.883 & 3.279 & 18.326 & 18.617 & 79.856 \\
\hline $\mathrm{C}_{3}$ & 56.027 & 3.032 & 19.351 & 19.587 & 81.095 \\
\hline SE \pm & 0.054 & 0.097 & 0.033 & 0.057 & 0.071 \\
\hline CD at 5\% & 0.166 & 0.369 & 0.103 & 0.187 & 0.218 \\
\hline
\end{tabular}

Each value is the average of three observations

*Cookies (40\% PMF) from Dhanshakti variety

$\mathrm{C}_{0}=$ Cookies without (MBC), $\mathrm{C}_{1}=2 \% \mathrm{MBC}, \mathrm{C}_{2}=4 \% \mathrm{MBC}, \mathrm{C}_{3}=6 \% \mathrm{MBC}$

Table.5 Textural characteristics of cookies*

\begin{tabular}{|c|c|c|c|}
\hline Treatments & $\begin{array}{c}\text { Hardness } \\
(\mathbf{N})\end{array}$ & $\begin{array}{c}\text { Breaking } \\
\text { strength }(\mathbf{N})\end{array}$ & $\begin{array}{c}\text { Cutting } \\
\text { strength }(\mathbf{N})\end{array}$ \\
\hline $\mathrm{C}_{0}$ & 11.58 & 38.97 & 40.16 \\
\hline $\mathrm{C}_{1}$ & 11.26 & 38.68 & 39.82 \\
\hline $\mathrm{C}_{2}$ & 10.97 & 38.33 & 39.65 \\
\hline $\mathrm{C}_{3}$ & 10.64 & 37.92 & 39.23 \\
\hline SE $\mathbf{\pm}$ & 0.033 & 0.071 & 0.054 \\
\hline CD at 5\% & 0.103 & 0.218 & 0.166 \\
\hline
\end{tabular}

Each value is the average of three observations

*Cookies (40\% PMF) from Dhanshakti variety

$\mathrm{C}_{0}=$ Cookies without (MBC), $\mathrm{C}_{1}=2 \% \mathrm{MBC}, \mathrm{C}_{2}=4 \% \mathrm{MBC}, \mathrm{C}_{3}=6 \% \mathrm{MBC}$

\section{Textural characteristics of cookies}

Textural characteristics of cookies (Table 5) were affected slightly with the increase in the level of MBC. The hardness, breaking strength and cutting strength of $\beta$-carotene enriched pearl millet based cookies ranged from 11.58 to $10.64 \mathrm{~N}, 38.97$ to $37.92 \mathrm{~N}$ and 40.16 to $39.23 \mathrm{~N}$, respectively. The decrease in hardness, breaking strength and cutting strength might be due to weakened gluten network which reduced the dough cohesiveness and strength due to addition of MBC. Sudha et al., (2007) reported improvement in texture of biscuits containing maltodextrin. Agrahar-Murugkar et al., (2014) reported similar decrease in cutting strength of composite flour biscuits.

In conclusion, the results of this study indicate laboratory prepared microencapsulated $\beta$-carotene has the potential for use in cookies enrichment.
Microencapsulation protected $\beta$-carotene during processing of cookies, thus maintaining its activity.

It was observed that pearl millet based cookies supplemented with MBC improved all the sensory characteristics of cookies. The physical and textural characteristics of cookies were slightly affected by MBC supplementation. The supplementation of MBC (4\%) in cookies was considered to be better on the basis of physicochemical, sensory and textural analysis of cookies.

\section{References}

AACC. 1976. American Association of Cereal Chemists $7^{\text {th }}$ Edn.

Agrahar-Murugkar, D., Gulati, P., Kotwaliwale, N. and Gupta, C. 2014. Evaluation of nutritional, textural and particle size 
characteristics of dough and biscuits made from composite flours containing sprouted and malted ingredients. J. Food Sci. Technol. DOI: 10.1007/s13197-0141597-y

Ajila, C. M., Leelavathi, K. and Prasada Rao, U. J. S. 2008. Improvement of dietary fiber content and antioxidant properties in soft dough biscuits with the incorporation of mango peel powder. J. Cereal Sci. 48: 319-326.

Bauernfeind, J. C., Smith, E. G. and Bunnel, R. H. 1958. Colouring fat-base foods with $\beta$ carotene. Food Technol. 12: 527-535.

Bram, P., Edith, W., Hans, G., Kristof, B. and Jan, A. D. 2008. The role of gluten in a sugarsnap cookie system: A model approach based on gluten-starch blends. J. Cereal Sci. 48: 863-869.

Bunnel, R. H., Discoll, W. and Bauernfeind, J. C. 1958. Colouring water-base foods with $\beta$ carotene. Food Technol. 12: 536-541.

Gayas, B., Shukla, R. N. and Khan, B. M. 2012. Physico-chemical and sensory characteristics of carrot pomace powder enriched defatted soyflour fortified biscuits. Int. J. Sci. Res. Publi. 2(8): 1-4.

Kowalski, R. E., Mergens, W. J. and Scialpi, L. J. 2000. Process for manufacture of carotenoid compositions. US Patent: 6,093,348.

Moore, J., Luther, M., Cheng, Z. and Yu, L. 2009. Effects of baking conditions, dough fermentation and bran particle size on antioxidant properties of whole-wheat pizza crusts. J. Agric. Food Chem. 57(3): 832-839.

Mridula, D. 2011. Physico-chemical and sensory characteristics of $\beta$-carotene rich defatted soy fortified biscuits. African J. Food Sci. 5(5): 305-312.

Panse V. S. and Sukhatme P. V. 1967. Statistical
Methods for Agricultural Workers. Indian Council of Agricultural Research. New Delhi. pp: 70-72.

Park, H., Seib, P. A., Chung, O. K. and Seitz, L. M. 1997. Fortifying bread with each of three antioxidants. Cereal Chem. 74(3): 202-206.

Rogers, D. E., Malouf, R. B., Langemeier, J., Gelroth, J. A. and Ranhotra, G. S. 1993. Stability and nutrient contribution of $\beta$ carotene added to selected bakery products. Cereal Chem. 70(5): 558-561.

Sheehy P. J. A. and Morrissey P. A. 1998. Functional foods: prospects and perspectives. In Nutritional Aspects of Food Processing and Ingredients, pp: 4565 [CJK Henry and NJ Heppell, editors]. Gaithersburg, MD: Aspen Publishers.

Singh, B., Bajaj, M., Kaur, A., Sharma, S. and Sidhu, J. 1993. Studies on development of high protein biscuits from composite flours. Plant Foods Human Nutr. 43(2): 181-189.

Singh, S. 2014. Vitamin-A deficiency - A big challenge for India. Protein Food Nutr. Dev. Assoc. India Bulletin. Aug. pp: 3-5.

Srivastava, R. P. and Kumar, S. 2009. Fruit and Vegetable Preservation: Principles and Practices. IBDC, New Delhi. pp: 360.

Sudha, M. L., Srivastava, A. K., Vetrimani, R. and Leelavathi, K. 2007. Fat replacement in soft dough biscuits: Its implications on dough rheology and biscuit quality. $J$. Food Engg. 80: 922-930.

Volker, B., Luh, N. I., Puspitasari, Ferruzi, M. G. and Schwartz, S. J. 2002. Trolox equivalent antioxidant capacity of different geometrical isomers of $\alpha$ carotene, $\beta$-carotene, Lycopene and Zeaxanthin. J. Agric. Food Chem. 50(1): 221-226.

\section{How to cite this article:}

Kulthe, A.A., S.S. Thorat and Lande, S.B. 2017. Preparation of $\beta$-Carotene Enriched Pearl Millet Based Cookies Int.J.Curr.Microbiol.App.Sci. 6(2): 1197-1203.

doi: http://dx.doi.org/10.20546/ijcmas.2017.602.136 